gray surface. The vessels are filled with a firm, mostly red laminated clot, which is adherent to the vessel walls in places, but which ean be detaclied and removed as a tree. The deseending aorta is the seat of several thickened patehes of sclerosis, from one to three centimetres in size. That vessel and the iliae arteries are free from elots. The heart eontained fluid blood and no clots.

ACUTE APPENDICITIS; OPERATION; SEPTIC THROMBO-

SIS OF A BRANCH OF THE RIGHT PULMONARY ARTERY, FOLLOWED BY ABSCESS OR GANGRENE OF THE LUNG; DEATH.

DR, LE Conte also reported the following case: A man, aged fifty-four years, was admitted to the Pennsylvania Hospital, September I5, I903, who liad been ill for five days with abdominal pain, vomiting, fever, eonstipation, the pain localizing itself in the right iliac region during the last forty-eight lours. No previons attack of this nature. On admission his temperature was $102^{2} / 0^{\circ}$ li.; pulse, I20; respirations, 32. Abdomen prominent, rigid, and tender only in riglit iliae region, where an illy defined sausageshaped mass could be made out on palpation.

The abdomen was opened throngh the right reetus must:le, exposing all appendix very large, much thickened, inflamed, red, and standing erect. Meso-appendix very thick and board-like. No perforation was visible in the appendix, but on one side there was a greenish spot. It contained pus and a faeeal eoneretion the size of a clicstnut. Intestines in the immediate neighborlood were in places of a gray-green color, like beginning gangrene. The appendix was removed, the surrounding abdominal eavity walled off from the green portions of the intestine, drainage inserted, and the abdominal wonnd partially closed. Baeterial eultures from the peritoneum slowed baeillus laetis aërogenes. Reaction following the operation was good, and the convalescence seemed to be well establislied, when on September 25 , ten days after the operation, he wakened from sleep in a condition of profound eollapse. The weakness was extreme; pulse very feeble; breathing difficult and shallow; temperature one degree subnormal; sweating profuse. No pain. Later in the morning there was severe pain beneatl the right scapula. No impairment of resonanec; no frietion sound or râles to be heard. 
September 26. There was suppression of the breath sounds over the base of the right lung posteriorly. No impairment of resonance; no friction murmur. Temperature had risen to $103^{\circ}$ F.; some cough ; no expectoration.

September 27. Resonance impaired over right base, where the breath sounds were very feeble. Congh continues with some bright, blood-red expectoration. Lencocyte count, 16,000; pain shooting through lower part of right clest.

September 28. Physical signs over right base similar to those of a central pnelmonia. Expectoration more free and still bright red. Pneumococcus and tubercle bacillns not found in sputum. Paticnt continued in this condition for about a weck, and then a slow improvement set in, although the tempcrature never quite reached normal.

By the igth of October a small, localized effusion was diagnosed over the right pleura. The sputum at this time was very copious, had lost its bloody characteristics, but was occasionally rusty. It was filled with pneumococci; breath a little offensive. Patient moderately septic with hectic temperature.

October 27. During a hard coughing spell a large quantity of foul-smelling, tenacious, yellowish material was brought up. An exploring needle was inserted into the chest and about a drachm of dark brown, thin fluid was cvacuated, with a freal odor. This fluid was loaded with streptococci and staphylococci, and with bacilli which were variously described as long and thin, short and stout, and square-ended.

October 28. Under local anxsthesia, induced by Sclileiclı's fluid, an attempt was made to open the chest. The pleura was opened and no fluid encountered. The hung within felt hard and solid. This procedure was so painful and clepressing to the paticnt that the operation was not persisted in. His condition at the time was profoundly septic, and it was not deemed advisable to give an anæsthetic. Owing to difficulty of respiration, he was constantly in a semirecumbent position, could not lie down.

November I. He was again tapped and purulent fluid of a very foul odor withdrawn. He positively refused any further operative procedures, and it was not until November 5 that he consented. At this time, while in a semisitting position anesthol was administered. After he became unconscious, it was found impossible to operate with the patient in this position, and it became nec- 
essary to turn him on his left side. Just as the skin was incised there was a violent expulsive cough, and from the mouth and nostrils a quantity of foetid, greenish pus gushed out. In a second, respiration ceased and stimulation and artificial respiration failed to revive the patient. Evidently the lungs were flooded with pus by the rupture of the abscess, and he was drowned in his own secretions.

Post-mortem examination was refused.

Dr. Le Conte said that his reasons for believing this case to be one of septic embolus of a branch of the right pulmonary artery were the following:

Suddemess of onset with collapse; diffieult respiration; fceble pulse; an absolute lack of physical signs at first, these developing in the following order, pain, impaired breath sounds, fever, briglt bloody expectoration, impaired resonance; at first no râles and no friction murmurs. With the meso-appendix enormously thickened and inflamed at the time of operation, it is not hard to believe that a septic clot detached itself from one of these vessels and was swept into the lower branch of the right pulmonary artery.

Dr. George Erety Shoemaker regarded the class of cases reported by Dr. Le Conte of interest as explaining some postoperative deatlis. Cases similar to the one which occurred soon after operation miglit be due to sudden heart failure. One peculiarity about cases of sudden death is that nearly all of them occur from a week to ten days after operation and in patients that are doing well; hence they come as a surprise. Such patients move about more than do those profoundly ill. Emboli are thus formed out of otherwise innocent local vein clots. They should teach the surgeon that it is unvise, even in simple cases of major operation, to allow the patient out of bed as early as the tenth day. Some surgeons even boast of their patients leaving the hospital on the tenth or even the fourth day; this adds to the risk. These remarks do not, of course, refer to Dr. Le Conte's cases. Dr. Shoemaker's experience witl embolism is limited to one case which oecurred after severe hamorrhage due to ruptured extra-uterine pregnancy. The patient was a large woman, wlio had a fatty heart and had previously suffered from perinepluritic abseess. Eetopic rupture occurred during the sixtl weck of gestation. After operation the pulse and temperature were normal at the ninth day, and the 
patient was supposed to be in splendid condition. She died instantly, no doubt as the result of a elot in the pulmonary vessels, though no post-mortem was lield. Most of the cases in which embolism occurs are simple in character, and for that reason the surgeon is apt to allow the patient early liberty. A similar variety of sudden death occurs after undue exertion during pneumonia.

Dr. Henry R. Whatron mentioned a case in which he performed Schede's operation for varieose veins of the leg. 'The patient recovered from the anæsthetic, but in five hours developed shortness of breath and soon died. There was in this ease some question as to whether there was pulmonary or eardiac embolism, as no post-mortem examination was made.

Dr. Le Conte added that cases of pulmonary embohns might be divided into two groups, the septic and the non-septic; and these again into large emboli and small oncs. In some eases where the embolus is aseptic and small, one of the smaller branclics of the pnlmonary artery may alone be oceluded, and the patient may present symptoms not dissimilar to syncope. There will be a rapid, feeble pulse, sliallow respiration, sweating, and usually pain in the lung. Such cases almost invariably recover, the attenting surgeon perhaps having entirely overlooked the fact that embolus has taken place. In other instances the non-scptic throunbus may be so large that the entire pulmonary artery is occhuded, and death is almost instantaneous.

In the septic group, if the primary thrombus is small and only a portion of the artery is oecluded, the patient recovers from the immediate shock, to develop later a septic pneumonia or gangrene of the lung. In such cases, then, the patient does not dic as a result of the oeclusion of the vessel, but rather on account of the septic material which has been cleposited in the lung.

\section{COMPLETE INTESTINAL OBSTRUCTION FROM A BAND AND VOLVULUS OF THE ILEUM.}

Dr. Robert G. Le Conte reported the ease of a man, aged forty years, who was admitted to the Pennsylvania Hospital, July 18, 1904, with a history of four attacks of appendicitis since June, 1903, culminating in an attack in April, 1904, when a large abscess in the region of the appendix was opened, but without the removal of the appendix. 